\title{
Bioclimatological Conditions of Hrubý Jesenik: Their Relationship with Synoptical Situations
}

\author{
Wojciech Szarek \\ Department of Geography, Faculty of Science, Masaryk University, Kotlarska 2, 61137 Brno, Czech Republic
}

Correspondence should be addressed to Wojciech Szarek, szarekwojciech@o2.pl

Received 7 February 2012; Accepted 25 March 2012

Academic Editors: I. Bordi, U. Kulshrestha, and P. Nastos

Copyright () 2012 Wojciech Szarek. This is an open access article distributed under the Creative Commons Attribution License, which permits unrestricted use, distribution, and reproduction in any medium, provided the original work is properly cited.

The focus of this paper is the characteristics of bioclimatological conditions of one popular touristic region in Czech Republic. Biometeorological conditions of the region were described from the point of view of energy exchange between human body and atmospheric environment. Influences of meteorological agents on human organisms are presented by using two indices based on MENEX model. Indices illustrate the physiological strain and subjective thermal feeling of a person exposed to thermal environment. Obtained values of indices were compared to synoptical weather types. Comparisons were provided for the most uncomfortable conditions. Groups of synoptical weather types that occur when biometeorological conditions are very uncomfortable were found.

\section{Introduction}

Outdoor active recreation is important factor that can improve the health state of the human body. Physical activity involves the circulatory system, helps to maintain correct body mass, protect organisms against various cancer diseases, and improves psychical processes [1].

Areas that offer the best conditions for physical activity are characterised by attractive natural environment and tourist infrastructure due to which it is possible to provide different types of physical activity. One of the regions used for various spectra of physical activity is Hrubý Jesenik, a mountain area with the highest point at the $1490 \mathrm{~m}$ a. s. l. (Praděd). The Hrubý Jesenik is located in the north part of the Czech Republic in Olomoucky kraj. This region offers possibilities of walking, cycling, skiing, cross-country skiing, paragliding, and spa.

The possibility of being outdoor and realising one of the types of activity is influenced by meteorological conditions. From a human biometeorological point of view, atmospheric conditions can be thermoneutral or provide physiological strain of human organisms. Their influence on human organism affects the subjective feeling about thermal environment. Influence of meteorological conditions on human body can be examined by tools used in human biometeorology. Popular tools are thermal models presenting exchange of energy between the human organism and the environment [2]. Results of research provided since the 20th century are, for example, thermal comfort equation [2], Stolwijk model, Werner model [3], and Memi model [4, 5]. During the last years besides models like Fiala model [6] or Rayman [7], MENEX model was developed $[8,9]$.

The MENEX model can be used in various spectra of climatological conditions and in diverse types of environment [10-12].

\section{Material and Methods}

The basic material for this paper is data originated from three meteorological stations of the Czech Hydrometeorological Institute: Staré Město, pod Kralickým Sněžníkem, and Praděd and Šumperk (Figure 1). Characteristics of stations are shown in Table 1.

Data used in this work are from daily measurement at 14 LMT and contain temperature and humidity of air on the level $2 \mathrm{~m}$ above ground level and wind speed measured at $10 \mathrm{~m}$ above ground level, recalculated at $2 \mathrm{~m}$ above ground level. Total cloudiness was used too. Wind speed was 


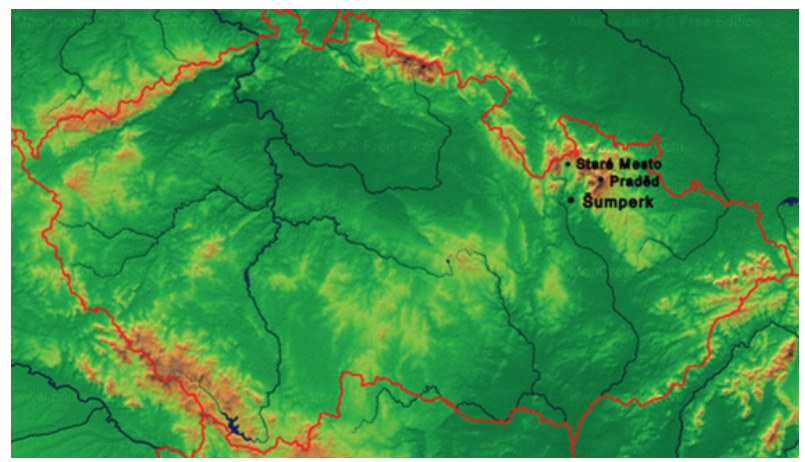

FIgURE 1: Location of stations in Czech Republic.

TABle 1: Characteristics of meteorological stations on which observations used in this work were provided.

\begin{tabular}{|c|c|c|c|}
\hline Station & $\begin{array}{l}\text { Period of observation } \\
\text { (years) }\end{array}$ & $\begin{array}{l}\text { Geographical } \\
\text { coordinates }\end{array}$ & $\begin{array}{l}\text { Elevation } \\
\text { (m a.s. } 1 .)\end{array}$ \\
\hline \multirow{4}{*}{$\begin{array}{l}\text { Staré } \\
\text { Město pod } \\
\text { Kralickým } \\
\text { Sněžníkem } \\
\text { Sumperk }\end{array}$} & $1964-1990$ & $16^{\circ} 56^{\prime} 36^{\prime \prime} \mathrm{E}$ & 658 \\
\hline & & $50^{\circ} 11^{\prime} 36^{\prime \prime} \mathrm{N}$ & \\
\hline & $\begin{array}{l}\text { 1961-1970 } \\
1974-1990\end{array}$ & $16^{\circ} 57^{\prime} 45^{\prime \prime} \mathrm{E}$ & 328 \\
\hline & $\begin{array}{l}\text { (since } 1971 \text { to } 1973 \\
\text { observations were not } \\
\text { provided) }\end{array}$ & $49^{\circ} 58^{\prime} 28^{\prime \prime} \mathrm{N}$ & \\
\hline \multirow{2}{*}{ Praděd } & \multirow{2}{*}{ 1961-1990 } & $17^{\circ} 14^{\prime} 02^{\prime \prime} \mathrm{E}$ & 1490 \\
\hline & & $50^{\circ} 04^{\prime} 58^{\prime \prime} \mathrm{N}$ & \\
\hline
\end{tabular}

recalculated according to the model of wind profile used in this type of biometeorological research [12]:

$$
v_{2}=v_{1} *\left(\frac{h_{2}}{h_{1}}\right)^{0.2}
$$

where: $h_{1}$ and $h_{2}$ indicate the height above ground level and $v_{2}$ and $v_{1}$ the wind speed at levels $h_{1}$ and $h_{2}$.

On the basis of meteorological data for a person doing physical activity with metabolic heat production equal to $135 \mathrm{~W} / \mathrm{m}^{2}$ simulations were provided. Example of this activity is walking with velocity $1.1 \mathrm{~m} / \mathrm{s}$ on area with no inclination. Simulations were provided according to the Man-Environment Heat Exchange Model Menex. Model is based on energy balance equation of human body [9]:

$$
S=M+m C+m E+m L+m R e s+m R,
$$

where: $S$ is the net heat storage, $M$ the metabolic heat production, $m E$ the heat losses by evaporation from body surface, $m C$ the turbulence exchange of heat by turbulence, $m R e s$ the total heat losses from the respiratory tract, $m L$ the long wave radiation from human body, and $m R$ the solar radiation absorbed by human body.

Detailed description of the model is available in [9]. On the basis of the MENEX model Physiological Strain (PhS) and Subjective Temperature Index (STI) calculations were used. This index indicates the influence of meteorological conditions on physiological reactions and subjective feelings about thermal environment.
Subjective Temperature Index (STI) indicates feeling of subjective thermal stimuli by person exposed on meteorological conditions before adaptative processes activation. Subjective temperature index is calculated with the following equations [13]:

if $S^{*}<0$,

$$
\mathrm{STI}=\mathrm{Mrt} \cdot-\left\{\left[\frac{\left|S^{*}\right|^{0.75}}{\left(5.38610^{-8}\right)}+273^{4}\right]^{0.25}-273\right\}\left[{ }^{\circ} \mathrm{C}\right],
$$

if $S^{*} \geq 0$

$$
\mathrm{STI}=\mathrm{Mrt} \cdot-\left\{\left[\frac{\left|S^{*}\right|^{0.75}}{\left(5.38610^{-8}\right)}+273^{4}\right]^{0.25}+273\right\}\left[{ }^{\circ} \mathrm{C}\right],
$$

where: Mrt is the mean radiant temperature $\left({ }^{\circ} \mathrm{C}\right)$ and $\mathrm{S}^{*}$ is the resultant net heat storage of human body $\left(\mathrm{W}^{*} \mathrm{~m}^{-2}\right)$. STI values grouped into classes corresponding to person subjective feelings as follows:

$$
\begin{aligned}
& \text { below }-38.0^{\circ} \mathrm{C} \text { : extremely cold, } \\
& \text { from }-38.1 \text { to }-20.1 \text { : very cold, } \\
& \text { from }-20.0 \text { to }-0.5 \text { : Cold, } \\
& \text { from }-0.4 \text { to } 22.5 \text { : Cool, } \\
& \text { from } 22.6 \text { to } 31.9 \text { : Comfortable, } \\
& \text { from } 32.0 \text { to } 45.9 \text { : Warm, } \\
& \text { from } 46.0 \text { to } 54.9 \text { : Hot, } \\
& \text { from } 55.0 \text { to } 70.0 \text { : very hot, } \\
& \text { above } 70.0 \text { : Sweltering. }
\end{aligned}
$$

Physiological Strain (PhS) is obtained with relation (5) between turbulence heat exchange $(m C)$ and evaporative heat losses $(m E)$ from human body [13]:

$$
\mathrm{PhS}=\frac{m C}{m E}(\text { dimensionless }) .
$$

Values of $\mathrm{PhS}$ indicate intensity of physiological strain caused by the environment. Values lower than 0.75 indicate hot strain connected with increase in peripheral blood flow and decrease in blood pressure, increase in heart rate, intensive sweating and dehydration, and temporal changes in skin temperature. If cold physiological strain occurs, $\mathrm{PhS}$ values are bigger than 1.5. Cold strain is connected with decrease in skin temperature, reduction of peripheral blood flow, increase in blood pressure, increase in thermal insulation of skin tissue, and/or shivering. Intensity of physiology strain and $\mathrm{PhS}$ values are related as follows [13]:

below 0.0: extreme hot strain,

from 0.00 to 0.24 : great hot strain,

from 0.25 to 0.74 : moderate hot strain,

from 0.75 to 1.50: thermoneutral (slight strain),

from 1.51 to 4.00 : moderate cold strain, 


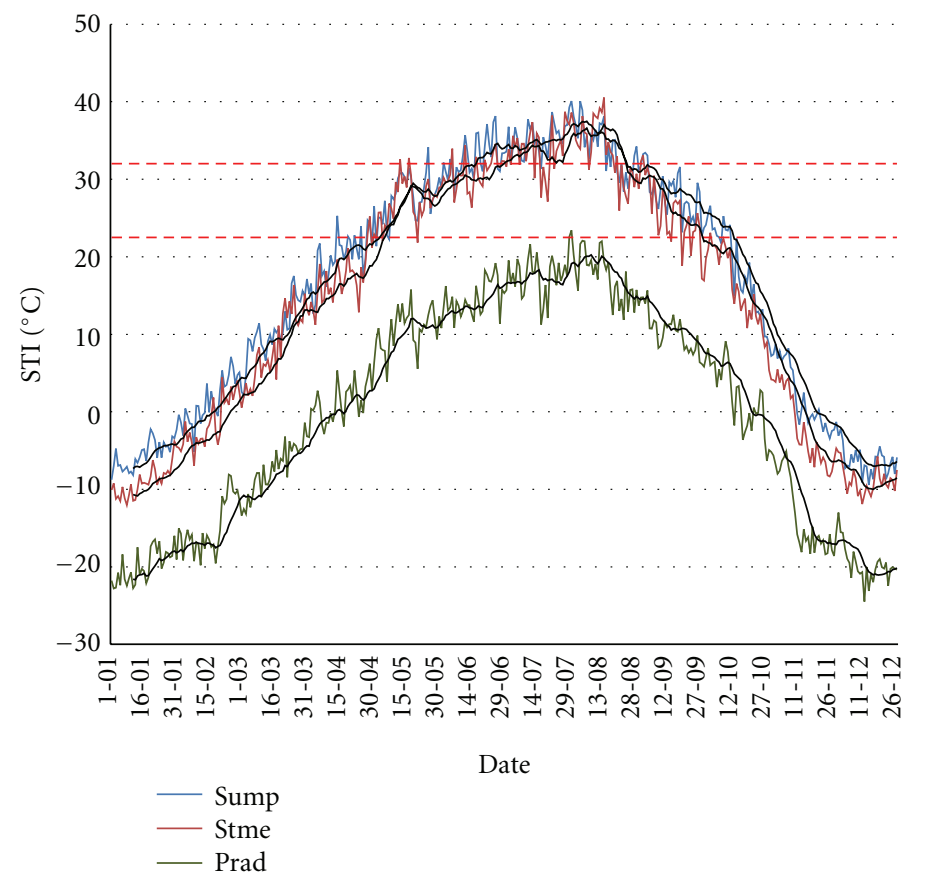

FIgURE 2: Mean annual course of STI in Hruby Jesenik based on values calculated for 14-hour mean local time at Šumperk (sump), Staré Město (stme), and Praděd (prad) stations. Black lines are mean 11-day values, and red dashed lines are thresholds of subjective feeling "comfortable."

from 4.01 to 8.00: great cold strain,

above 8.00: extreme cold strain.

Obtained values of the STI index indicated uncomfortable feelings: "cold," "very cold," "extremely cold," and "hot," "very hot," and "extremely hot" were correlated with synoptical weather types. The same procedure was provided for $\mathrm{PhS}$ values adequate to great and extreme strain caused by hot or cold. The system of synoptical situations was prepared by the Czech Hydrometeorological Institute and is used by meteorologists who work there $[14,15]$. The calendar of situations is available free at the Czech Hydrometeorological Institute website [16].

Results of calculations are values of biometeorological indices: Subjective Temperature Index (STI) and Physiological Strain (PhS). Calculations were done with Bioklima 2.5 software. Days with values that indicate uncomfortable subjective feeling or great physiological strain were in the next step correlated with the synoptical situation. The base of the system is the location.

\section{Results}

3.1. Bioclimatological Conditions Based on Subjective Temperature Index (STI). According to the mean annual course of values of Subjective Temperature Index (STI) calculated for 14-hour mean local time at three stations Šumperk, Staré Město, and Praděd, the highest values were at Šumperk. The lowest values were on the highest parts of the Jesenik massif represented by Praděd station (Figure 2). The amplitude of the annual course of mean values was about $40^{\circ} \mathrm{C}$. In July mean STI values were the highest, corresponding to subjective feeling "comfortable." In winter (December, January, and February) these values were the lowest (about $-20^{\circ} \mathrm{C}$ ), corresponding to subjective feeling "very cold." Analogical course calculated for Šumperk and Staré Město stations were similar, however for Šumperk station values were slightly higher. The amplitude of the annual course for these stations was about $50^{\circ} \mathrm{C}$. On both stations values calculated for the winter season were in the range of subjective feeling "cold," while the highest values were corresponding with subjective feeling-"warm."

Frequency of the appearance of subjective feelings based on STI shown in Figure 3 is adequate to curves presented in Figure 2. A person being at Šumperk station can describe thermal environment, depending on season of course, using terms from "very cold" to "hot." At Staré Město types of subjective feelings were the same as at Šumperk station, however only at Staré Město feeling "very hot” occurred. Person exposed to outdoor conditions at the highest point of the Jesenik massif can characterise thermal environment from "extremely cold" to "hot." The feeling "hot" appeared very rarely.

Frequency of appearance of cold discomfort was the highest at Praděd station. Within the season from December to February $100 \%$ of the time cold discomfort can be felt. Particularly, in December and January discomfort can be described like "very cold" $50 \%$ of the time, and "cold" $40 \%$ of the time; each of the feelings "extremely cold" and "cool" takes $5 \%$ of the time. During summer months cold discomfort can be felt $60 \%$ of the time. A person being at Praděd station can feel "cool" $50 \%$ of the time and "cold" about $10 \%$ of the time in July (Figure 3 ). 


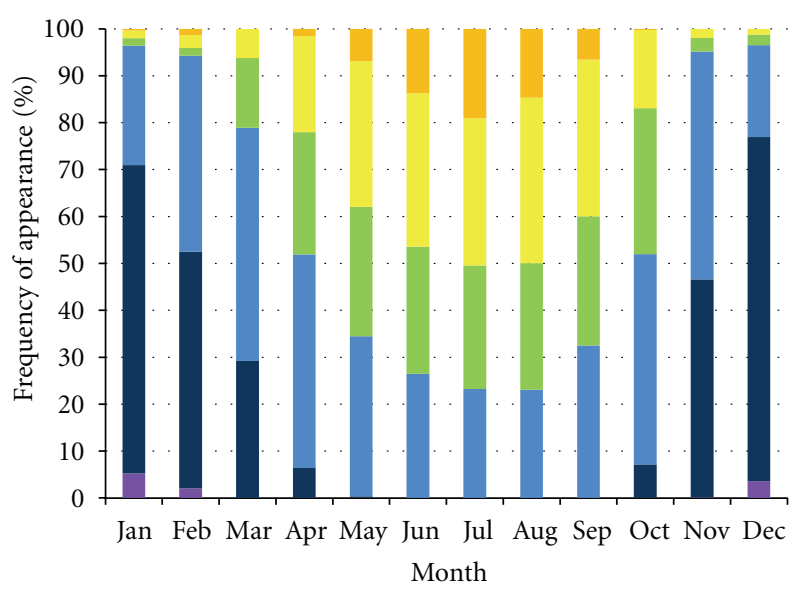

(a)

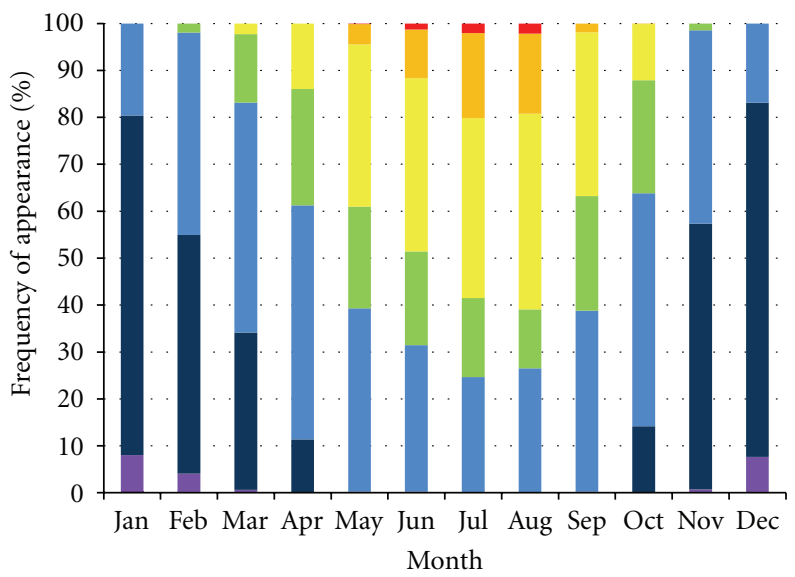

(b)

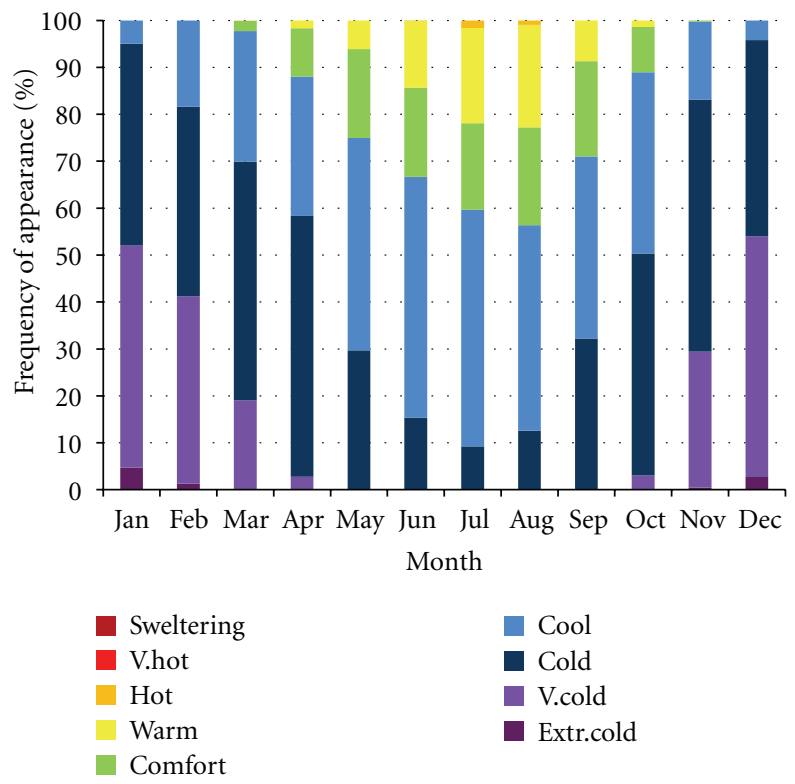

(c)

FIGURE 3: Frequency of appearance of different types of subjective feeling of thermal environment in each month based on Subjective Temperature Index at (a) Sumperk, (b) Staré Město, (c) Praděd.

At Staré Město station in December and February cold discomfort appeared all the time, and at Šumperk within $95 \%$ of the time. Uncomfortable conditions $70 \%$ of the time in December can be described as "cold." Thermal environment can be percepted as "very cold" at Staré Město and Šumperk 10 and $5 \%$ of the time, respectively. Cold discomfort can appear each month. During July at Šumperk and Staré Město a person can feel "cool" one-fourth of the time.

Meteorological conditions that can provide subjective feeling "comfortable" can appear all the year at stations Šumperk and Staré Město. The lowest frequency of comfortable conditions was there in winter months, on the level below 5\%. The maximal frequency of appearance of thermal comfort at Šmperk is in the period from April to October, when a person being at this location $25 \%$ in each month can feel "comfortable" of the time. At Staré Město station the highest frequency of the comfortable conditions is in April and October, on the level close to $25 \%$, whereas in summer months thermal comfort takes there $12 \%$ of the time. At Praděd station thermal comfort can be perceived by a person being there from April to November, most often in August, with frequency about $25 \%$.

Hot discomfort appears at Šumperk and Staré Město stations within the period from March to October. In summer months hot discomfort takes about half of the time at these locations. Discomfort was felt mainly as "warm" (30\%) and "hot" (20\%). At Praděd meteorological conditions can cause hot discomfort from May to September, most often in September, when frequency reaches up to $20 \%$ of the time. Hot discomfort was represented there practically only as "warm." Subjective feeling "hot" was present less than $1 \%$ of the time in July (Figure 3). 


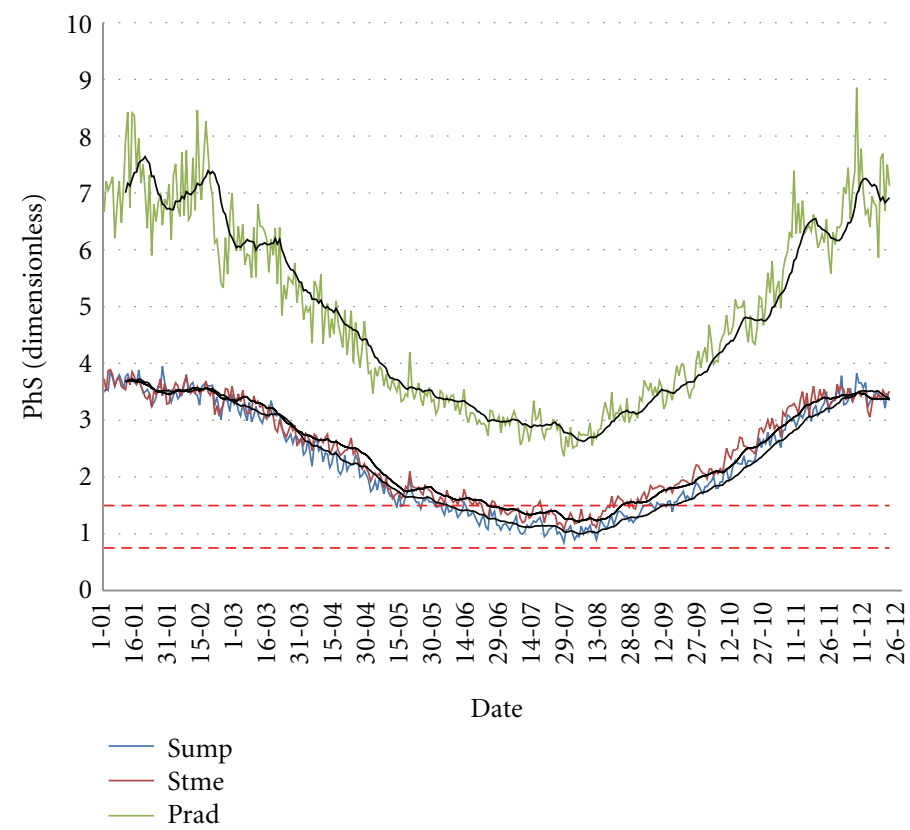

Figure 4: Mean annual course of PhS in Hruby Jesenik basis on values calculated for 14 hour mean local time at Šumperk (sump), Staré Město (stme) and Praděd (prad) stations. Black lines are mean 11 day value, red dashed lines are thresholds of thermoneutral conditions.

3.2. Biometeorological Conditions Based on the Physiological Strain Index. Daily mean values of PhS calculated for Praděd station reach maximal level, close to 8 , in winter months, January and December. The lowest values of the index (about 3) are in summer months. Annual course of Physiological Strain values at Šumperk and Staré Město stations are similar, with slightly higher values at Staré Město. For winter at both stations mean daily values are close to 4 . In summer season minimal values are close to 1 , indicating thermoneutral conditions (Figure 4).

At Praděd station only for summer months (from June to September) for $5 \%$ of the time were present conditions different than those causing cold strain. For the rest of the year only the cold strain was present. Extremely cold strain can appear from October up to April, with maximum frequency in January, close to $30 \%$, and minimal frequency in April ( $5 \%$ of the time). Great cold strain at Praděd can be caused by meteorological conditions in all the months, most often in December and January with $60 \%$ of the time. The lowest frequency in the year is in July when the great cold strain can take $15 \%$ of the time. The moderate cold strain affects human organisms most often in July (75\%) against the lowest frequency in January (15\%) (Figure 5).

At Šumperk and Staré Město stations the cold strain involving human organisms is mainly moderate. From November to March at both stations only cold strain is present. Percentage of time with cold strain is the lowest in the summer months and takes in Šumperk 25\% and in Staré Město about $40 \%$ of the time which occurred only as moderate cold strain. The great cold strain can be present in the period from November to March with frequency $10 \%$ and 25\% in March and January, respectively (Figure 5).
Meteorological conditions causing slight physiological strain at Praděd take less than 5\% of the time in June to September. At Šumperk station thermoneutral conditions can be present in all the months, while at Staré Město in the period March-October. Annual maximum frequency of thermoneutral conditions appears in July, close to $40 \%$.

The physiological heat strain does not appear at Praděd station. A person being at Šumperk can be affected by physiological heat strain from May to September practically. The frequency of heat strain appearance $(30 \%)$ is highest in July and September. Human organisms are exposed mainly to moderate heat strain. The great heat strain in summer takes about $5 \%$ of the time. Even winter months the heat strain can occurr, but very rarely. At Staré Město the heat strain appeared from May to September with the highest frequency in July, close to $17 \%$ of the time (Figure 5).

\subsection{Relations between the Most Uncomfortable Conditions and Synoptic Situations}

3.3.1. Correlation of Great and Extreme Physiological Strain with Synoptical Situations. Occurrence of unfriendly conditions that can affect unpleasant subjective feeling and physiological strain is related to some types of synoptic situations. At each of the stations the great cold strain mostly occurs when the following synoptical situations appear: low pressure over central Europe "B"; cyclonic situations: east (Ec), north (Nc), north-west (NWc), west (Wc, Wcs). Anticyclonic situations that often occur with the great cold strain are the following: anticyclonic (A), migratory anticyclone $(\mathrm{Ap})$, east $(\mathrm{Ea})$, and north-east (NEa). 


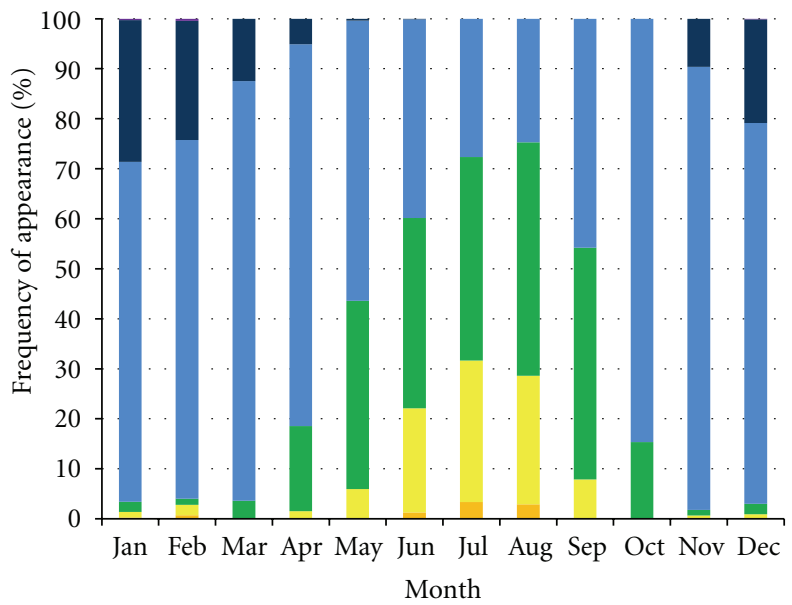

(a)

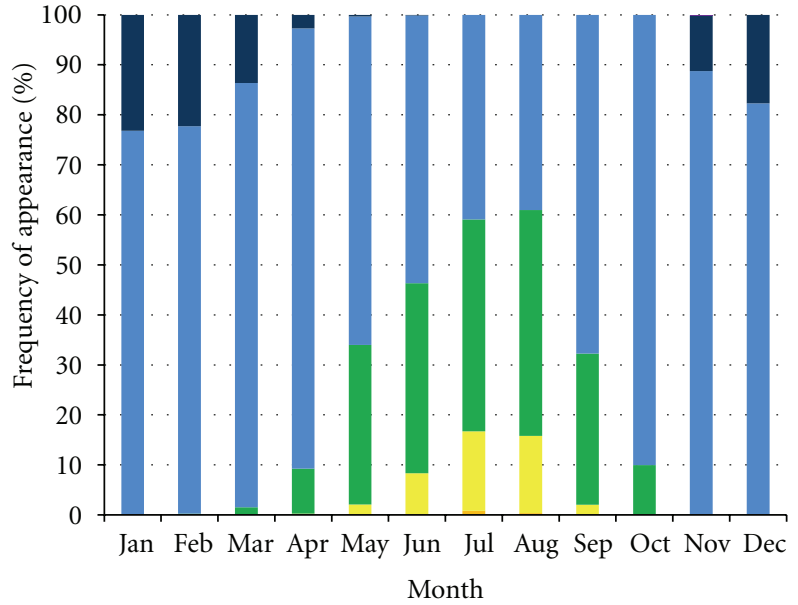

(b)

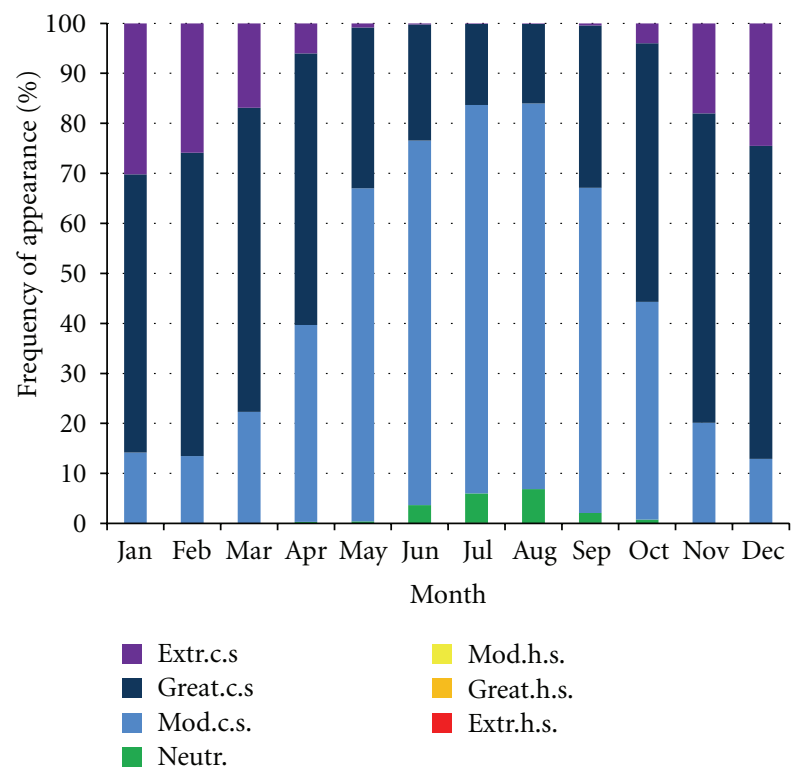

(c)

FIGURE 5: Frequency of appearance of different types of intensity of physiological strain in each month based on PhS index at (a) Šmperk, (b) Staré Město, (c) Praděd.

At Praděd station the great cold strain was present with some other synoptic situations, west anticyclonic (Wa) and south-west anticyclonic (SWa), and with cyclonic situations, south-west (SWc), additionally with passage of a front. The extreme cold strain at Šumperk and Staré Město occurred only few times per 30 years. On top of Praděd the extreme cold strain occurred together with the following situations: east anticyclonic $(\mathrm{Ea})$, west cyclonic (Wc, Wcs), north-west cyclonic (NWc), north-east anticyclonic (NEa), cyclonic (C), west cyclonic (Wc), and low presure through (B) and low pressure through passage (Bp). The great heat strain, which practically occurs occasionally only at Šmperk is connected with the following situations: anticyclonal (A), east anticyclonal, south-west anticyclonal (SWa), west anticyclonal (summer type), and south-west cyclonal (SWc). Extreme heat strain occured at Šumperk only, during presence of south anticyclonal situations (Sa) (Figure 6).

\subsubsection{Correlation of Appearance of Uncomfortable Subjective} Feeling Based on STI with Synoptical Situations. Subjective feeling "very cold" was connected in most of cases with cyclonic situations: cyclonic (C), north cyclonic (Nc), east cyclonic $(\mathrm{Ec})$, north-east cyclonic $(\mathrm{NEc})$, north-west cyclonic $(\mathrm{NWc})$, and low pressure over central Europe (B). At Praděd only additionally "very cold" feeling occurred with anticyclonic situation (A), front passage (Vfz), and cyclonic situations: south-west (SWc) and west (Wc, Wcs) (Figure 7).

At Staré Město station subjective feeling "extremely cold" occurred occasionally, and at Praděd more frequently. When 


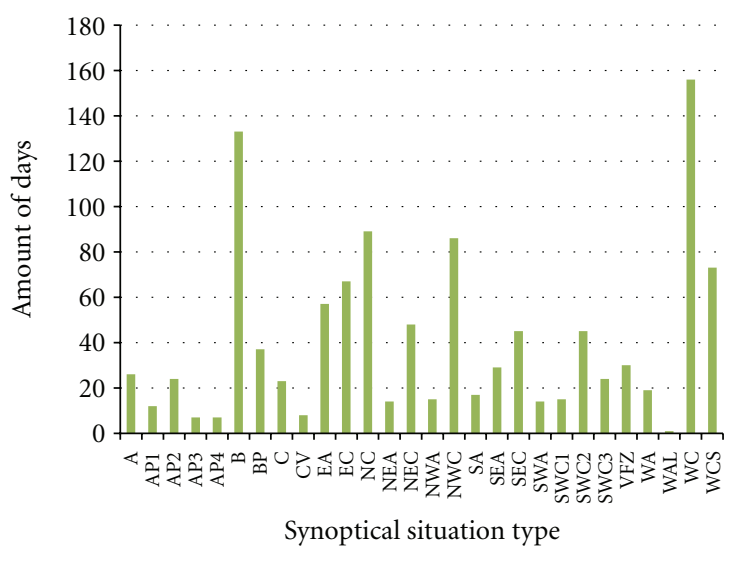

$\square \operatorname{Prad}$

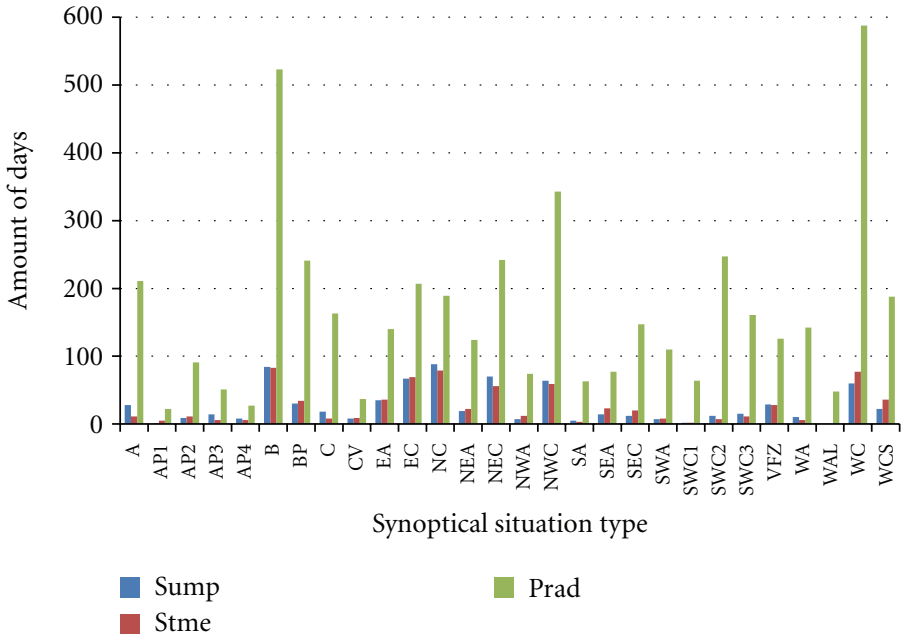

(b)

(a)

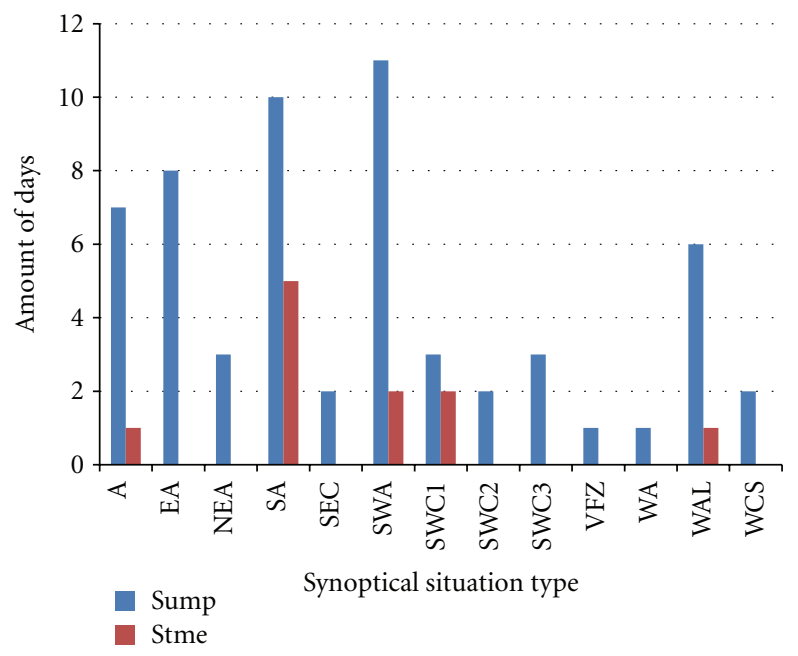

(c)

FIGURE 6: Number of appearances of the extreme cold strain (a), great cold strain (b), and great heat strain (c) related to synoptical conditions.

it occurred, the following cyclonic situations were present: east cyclonic $(\mathrm{Ec})$, north-east cyclonic $(\mathrm{NEc})$, north cyclonic $(\mathrm{Nc})$, north-west cyclonic (NWc), and low pressure through (Bp).

Subjective feeling "very hot" occurred at Šumperk and Staré Město stations only. This type of perception of thermal environment was connected in most cases with anticyclonic situations: anticyclonic (A), south-west (SWa), west anticyclonic (summer type) (Wal), and east anticyclonic (Ea). Cyclonic situations connected strongly with "very hot" feeling were: south-west (Sw, Swc1, Swc2, and Swc3 (Figure 7)).

\section{Conclusions}

The cold strain caused by weather stimuli was the greatest in the highest parts of Hrubý Jesenik. No hot strain occurred there. The cold strain occurred there more often than in lower parts. In lower parts, represented by Šmperk and Staré Město, human organisms can be affected by the cold strain and the hot one as well. Percentage of time with conditions providing to physiological strain is increasing with the height above sea level. Subjective perception of thermal environment as "comfortable" was most often at Šmperk. Frequency of comfortable conditions is decreasing with increasing the height above sea level.

The relationship between uncomfortable subjective feelings and physiological strain with synoptical situation shows that greatest possibility of the presence of cold discomfort and cold physiological strain appeared with air masses flow from north directions in cyclonic situations and low pressure through. Anticyclonic situations can provide uncomfortable feeling as well. For outdoor activities summer are most useful months. 


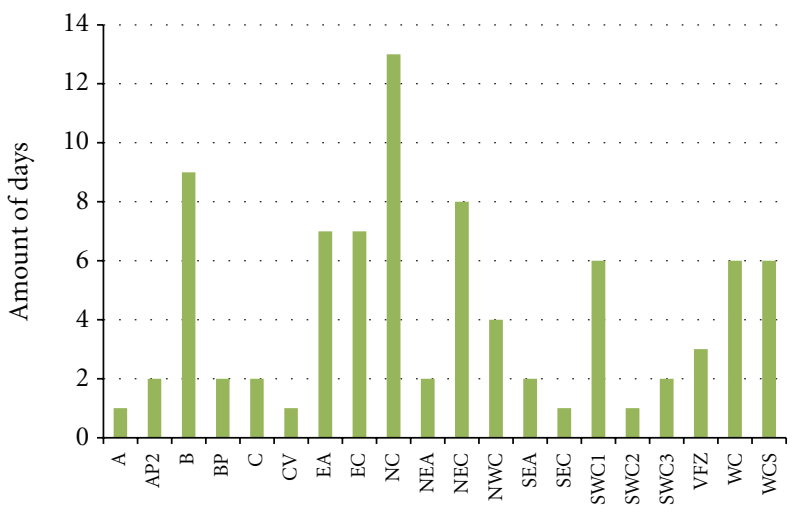

Synoptical situation type

Prad

(a)

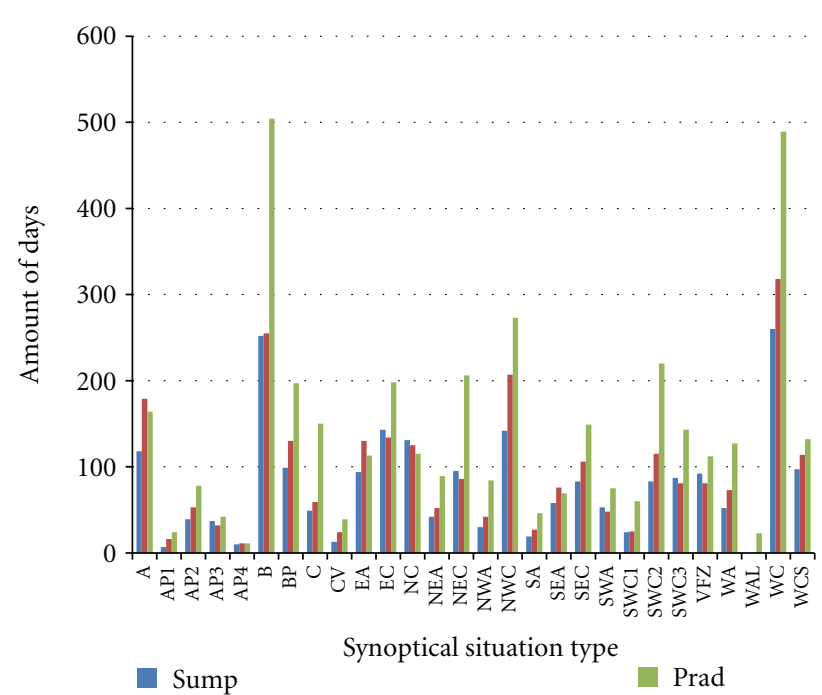

- Stme

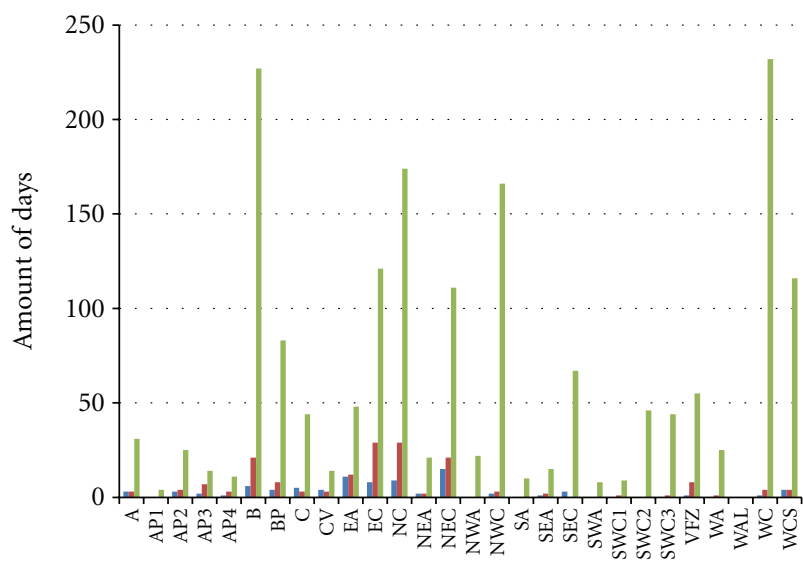

Synoptical situation type

- Sump

- Stme

(b)

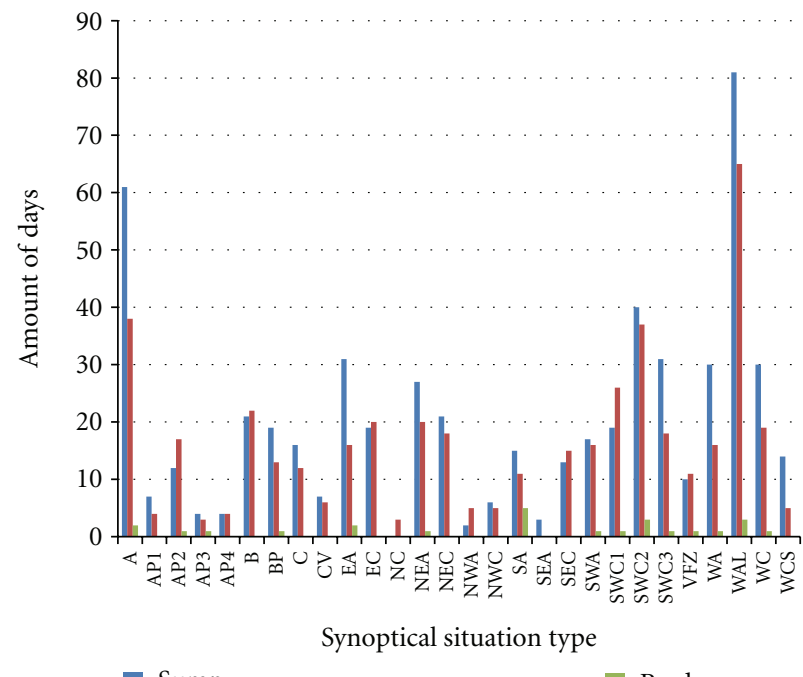

- Sump

- Stme

(d)

(c)

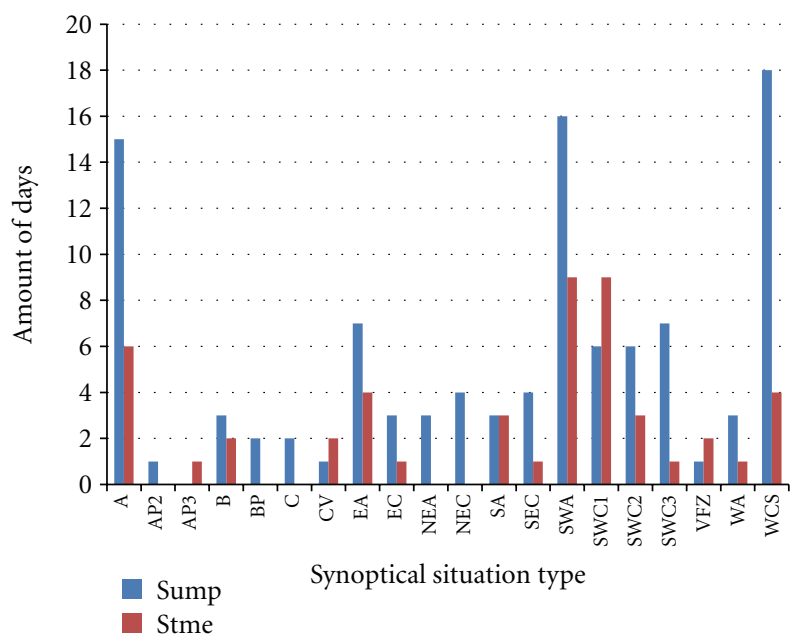

(e)

FIGURE 7: Number of appearances of subjective thermal feeling based on STI: extremely cold (a), very cold (b), cold (c), hot, and (d) very hot (e). 


\section{References}

[1] M. Bąkowska and K. Błażejczyk, “Zmienność warunków biotermicznych okresu letniego w Kołobrzegu w II połowie XX wieku," Przeglad Geograficzny, vol. 79, no. 2, pp. 215-232, 2007.

[2] K. Błażejczyk, "Asesment of regional bioclimatological contrast in Poland," Miscellanea Geographica, vol. 15, pp. 79-91, 2011.

[3] K. Błażejczyk, "Klimatologiczno-fizjologiczny model wymiany ciepła między człowiekiem i otoczeniem (MENEX)," Przegląd Geograficzny, vol. 66, no. 1-2, pp. 33-55, 1994.

[4] K. Błażejczyk and A. Matzarakis, "Assesment of bioclimatology differentiation in Poland based on the human heat balance," Geographia Polonica, vol. 80, no. 1, pp. 63-82, 2007.

[5] K. Błażejczyk, "New indices to asses thermal risk outdoors," in Proceedings of the 11th International Conference on Environmental Ergonomics, I. Holmer, K. Kuklane, and C. Gao, Eds., Ystad, Sweden, May 2005.

[6] J. Brádka, A. Dřevikovský, Z. Gregor, and J. Kolesár, Počasí na území Čech a Moravy v Typických Povětrnostních Situacích, HMU, Praha, Czech Republic, 1961.

[7] P. O. Fanger, Thermal Comfort, Danish Technical Press, Copenhagen, Denmark, 1970.

[8] D. Fiala, K. J. Lomas, and M. Stohrer, "A computer model of human thermoregulation for a wide range of environmental conditions: the passive system," Journal of Applied Physiology, vol. 87, no. 5, pp. 1957-1972, 1999.

[9] P. Höppe, "Different aspects of assessing indoor and outdoor thermal comfort," Energy and Buildings, vol. 34, no. 6, pp. 661665, 2002.

[10] P. Höppe, “The physiological equivalent temperature - A universal index for the biometeorological assessment of the thermal environment," International Journal of Biometeorology, vol. 43, no. 2, pp. 71-75, 1999.

[11] A. Matzarakis and F. Rutz, "Rayman: a tool for tourism and applied climatology," in Development in Tourism Climatology, A. Matzarakis, C. R. de Freitas, and D. Scott, Eds., pp. 129-138, 2007.

[12] K. C. Parson, Human Thermal Environments, Taylor and Francis, London, UK, 1993.

[13] R. S. Rosenberger, T. R. Bergerson, and J. D. Kline, "Macro linkages between health and outdoor recreation: the role of parks and recreation providers," Journal of Park and Recreation Administration, vol. 27, no. 3, pp. 8-20, 2009.

[14] S. Sikora, Bioklimat Wroclawia, Rozprawy Naukowe Instytutu Geografii i Rozwoju Regionalnego Uniwersytetu Wroclawskiego, Wrocław, Poland, 2008.

[15] http://portal.chmi.cz/portal/dt?action=content\&provider= JSPTabContainer\&menu=JSPTabContJSPTa/P4_Historicka_ data/P4_1_Pocasi/P4_1_12_Typizace_situaci\&nc=1\&portal_ lang=cs\#PP_TyTypiza_situaci.

[16] http://portal.chmi.cz/portal/dt?portal_lang=cs\&nc=1\&menu= JSPTabContainer/P4_Historicka_data/P4_1_Pocasi/P4_1_12_ Typizace_situaci\&last=false. 

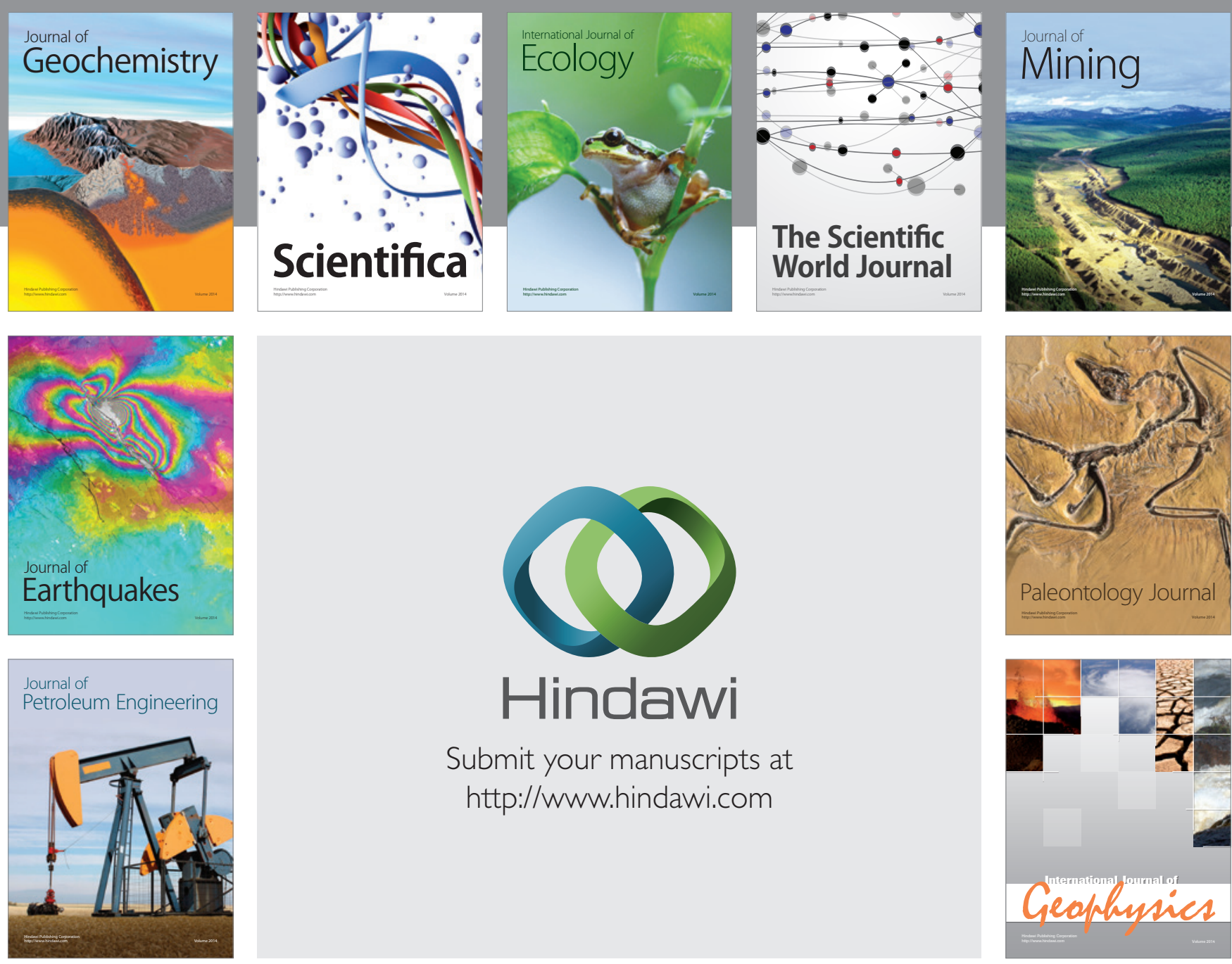

Submit your manuscripts at

http://www.hindawi.com
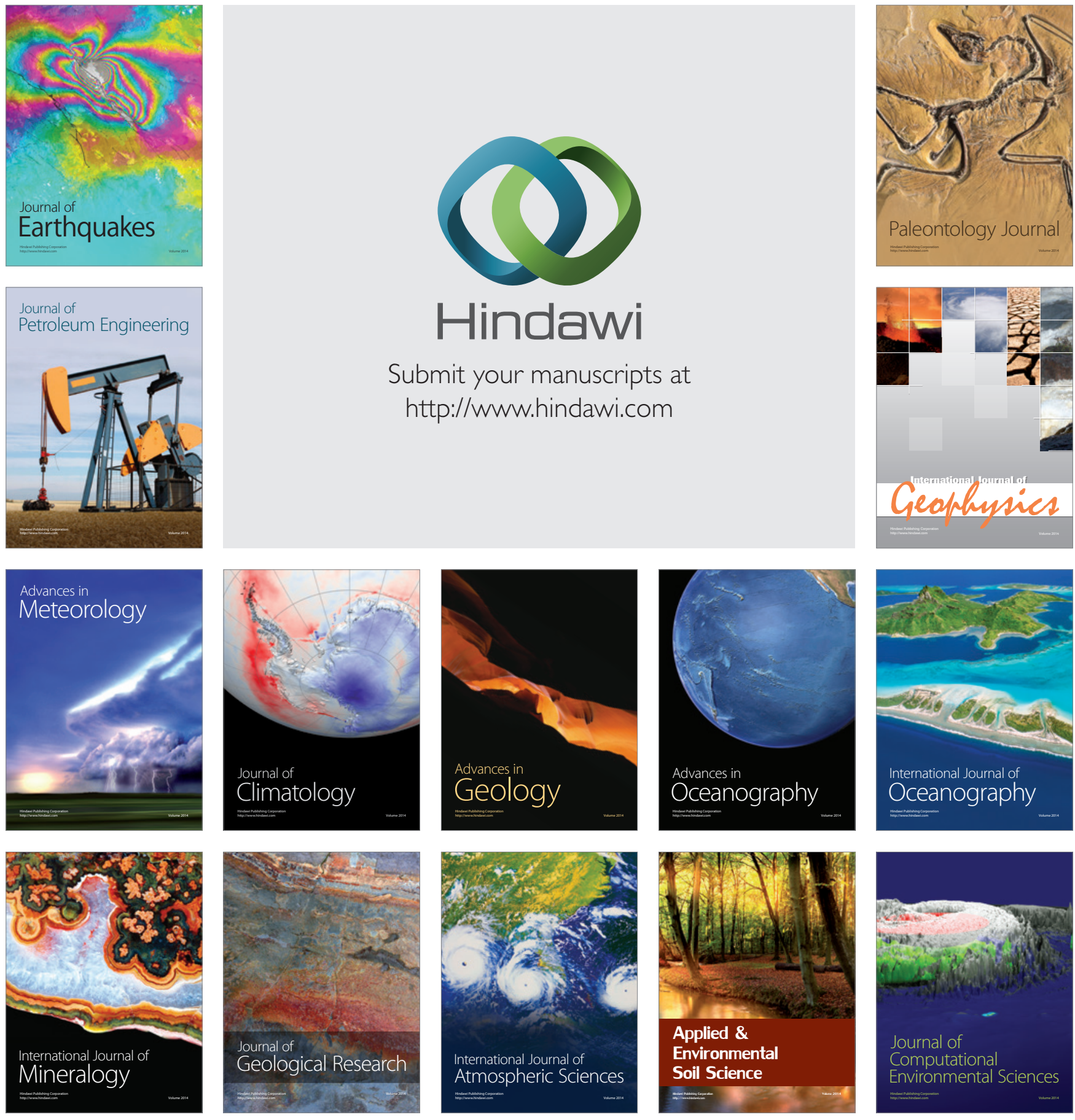